Published as: Bassens, D., E. Engelen, B. Derudder \& F. Witlox (2013) "Securitization across borders:

Organizational mimicry in Islamic finance". Journal of Economic Geography. Vol. 13 (1), pp. 85-106.

\title{
Securitization across Borders: Organizational Mimicry in Islamic Finance
}

Abstract: This paper discusses the case of securitization in Islamic finance to tease out what is universal and what is specific about this technique. To do this, the paper frames the spatial dispersal of securitization as a form of 'organizational mimicry', which highlights that techniques always rely for their functioning on locally rooted 'cultures of practice', suggesting that successful transplantations require adaptation in both context and technique. This paper adds to the prevalent literature on mimicry a geographical perspective by investigating to what extent this double shift can also be traced in the geo-historical dispersal of securitization in Islamic markets.

Keywords: Emerging markets, Gulf cities, Islamic finance, financial geography, IFCs

JEL Classification: G01, G15, G24, N25, N95 


\section{Introduction}

On February $3^{\text {rd }} 2011$, when Egyptian protests added another day of mass-mobilizing at Tahrir square - protests which ultimately resulted in Mubarak's downfall - the Dubai-based property developer Emaar launched its latest sukuk (Islamic bonds) on the London Stock Exchange (LSE), thereby reasserting its ambition to tap into global capital markets. As can be read of from the following communication by the Financial Times (FT, 2011) "the region's largest developer, builder of the world's tallest tower, issued the five-and-a-half-year Islamic bond as part of a broader US $\$ 2 \mathrm{bn}$ programme, paying a profit (equivalent interest) rate of 8.5 per cent (own emphasis added)." While at first glance unrelated, these two facts point to the paradoxical ubiquity of exceptionalism in knowledge production on the Arab world. On the one hand, the persistence of orientalist cum developmentalist perspectives on the Arab World are illustrated by the fact that the social and political upheaval denominated as the 'Arab Spring' is generally understood as the embodiment of a long-due transition towards modernity of a region that is hence perceived as not yet 'modern' or 'developed'. Yet at the very same time, as is illustrated by the FT report quoted above, the financial geographies of the Arab world show intense insertion in 'highly-advanced' financial markets, which are feeding spectacular hyper-modern urban-centred growth throughout the Gulf region.

However, as we discuss in this paper, exceptionalist readings of the Arab world are intensely propagated by often self-orientalising undercurrents within financial geographies of the Islamic world and the existing knowledge production thereon, even while the actual practices may prove otherwise. In particular, Islamic financial markets, which constitute the scope of this article, are persistently constructed as 'different', 'non-conventional' and even 'exotic'. Discursively Islamic markets are constructed as non-conventional on the basis of their grounding in Islamic faith - not in the least by Islamic financial elites themselves. Islamic practices in turn are generally conceived to be taking place outside or, at best, 'at the borders' of conventional financial networks, thus remaining largely untouched by crises triggered by the 'toxic assets' that circulated widely in conventional circuits (Hasan and Dridi, 2010). In this paper, we critically engage with the alleged exceptional stance of Islamic markets and analyse what makes these markets in fact non-conventional or 'Islamic'. We aim 
to undertake such an effort because even a superficial glance at contemporary practices in Islamic securitization markets - for instance, the paying of profits equivalent to interest - suggests the complete opposite of these perceptions. In fact, as the issuance of the Emaar Sukuk on the LSE illustrates, 'Islamic' products are gaining prominence in conventional investment portfolios. Moreover, this issuance also suggests that evolutions in Islamic markets are in line with the broadscale globalization and financialization of Middle Eastern economies, whereby Gulf international financial centres in particular are becoming regular nodes on global financial flows.

This paper then sets out to answer the difficult question of how concepts and practices of 'the Islamic' and 'finance' can be merged. In other words, we aim to analyse how 'Islamic' Islamic finance 'really' is in its contemporary form and what could be the implications of the potential discrepancies or similarities with conventional products, both for the way in which we conceptualize the process of globalization of Gulf financial markets and of financialization itself. To this end the paper focuses on the differences and similarities between standard Anglo-American securitization and securitization Islam style. As such the paper adds to a young but growing body of research on the geographies of securitization, which is geared towards studying how securitization adapts itself to various contexts. Wainwright (2009) spelled out how the technique first ended up in the UK, and how that required subtle adaptation in both technique and legal context. Aalbers et al. (2011) pursued this agenda and focused on residential mortgage backed securitization in the Netherlands, emphasizing in particular the responsive role of regulators to facilitate the growth of the securitization market in the Netherlands. Recently, a couple of agency reports have undertaken similar investigations of securitization in Italy, Denmark, and Australia (Albertazzi et al., 2011; Frankel et al., 2004; Rajapakse, 2005). The emphasis in these studies is more on what has made securitization in these latter three countries 'safer' than in the US than on the modifications that were required to make it work in the first place.

Here we aim to take the main thrust of such a body of literature on securitization - the basic observation of the 'plurality' of global finance, which also reverberates what Brenner et al. (2010) 
have called variegated neoliberalism - a step further. One way would be to frame this plurality as a cultural issue that has been described by anthropologists as 'vernacular modernity' or 'multiple modernities'. Following recent anthropological studies that have demonstrated that 'global modernity is always site-specific' (Appadurai, 1996; Eisenstadt, 2000; Knauft, 2002), our study will suggest that the 'hypermodern' field of finance too appears to be 'plural because in every local site modernity is brought into social existence in a tension-filled relationship between local concerns and global forms of discursive and institutional power' (Pieterse, 2000). Though clearly relevant, this anthropological point of view, however, mostly operates at the scale of coherent societies and/or cultures and as such plays itself out at a level of abstraction that is too far removed from our empirics to be able account for the specifics of our case. A more fruitful approach, so we contend, is to interpret developments in Islamic securitization markets through the lens of literatures that have put 'organizational mimicry' at the centre of their analysis. As such we will confront research on geographies of securitization with insights that have been generated by the growing social science literature on what is termed 'mimetic isomorphism' in organizational sociology (see DiMaggio and Powell, 1983 for the classic statement).

While based on different theoretical perspectives and using different empirical vignettes to make their point, such a literature demonstrates convincingly that socio-technical assemblages that at first sight appear to be universally applicable in fact require subtle adaptations to be able to 'work' satisfactory in other environments than those of their gestation. For instance, economic historians have shown the impact of contextual changes on the back of detailed empirical investigations of the introduction of new managerial models, demonstrating that the introduction of these models generated unintended negative consequences which had to be repaired, either through adaptations in the models themselves or in the legal, social, cultural environment or both (Djelic, 1998; Zeitlin and Herrigel, 2000). Recently this approach has increasingly been applied to account for the attempts by transnational professional elites to construct supranational conventions for accountancy, bookkeeping, financial management and other widely used 'metrics' (Djelic and Quack, 2007). Geographers have been quick to focus on the variegated spatial articulations of these 'metrics' and their professions, and have investigated the role of MBA's in furthering financial knowledge (Hall, 2006; 2008; Hall and 
Appleyard, 2009), of legal firms in promulgating a particular view of legal professionalism (Faulconbridge and Muzio, 2009), the 'construction' of a transnational executive market by headhunters (Beaverstock et al., 2010) as well as the role of analysts and fund managers in 'constructing' global asset categories (Lai, 2006; Sidaway and Bryson, 2002; Sidaway and Pryke, 2000).

In all of the above instances, the story is basically the same: models, techniques, technologies, administrative conventions, organizational blueprints do not simply consist of standard operating procedures that reduce agents to mere rule takers, but are embedded in mostly implicit and mostly local cultures of practices that either have to be imitated or reworked into the mimetized artefact to make them function, conceptually transforming agents from pure rule takers into partial rule makers. As our case on Islamic securitization will show such processes are fundamental in contemporary practices of global finance. To make our point the paper is structured as follows. The next section provides quantitative background information on the growth of the sukuk market. Section three traces the spatial history of securitization in the Islamic world through a qualitative description of the different sukuk markets. The fourth section then presents in more detail the case of the Emaar Sukuk to demonstrate the spatial and content-wise interconnectedness of Islamic finance with mainstream financial players and markets. Section five discusses the differences and similarities of Islamic sukuk structures with Anglo-American securitization, framing it as an instance of organizational mimicry and asking how to weigh what is different and similar. The final section wraps up and draws some tentative conclusions from this study for the remit of economic geography and the kind of crossdisciplinary dialogues it should engage in post crisis.

\section{Size and scale of the sukuk market}

Throughout the Islamic world, Islamic finance is growing as a set of powerful discourses and practices that mediate integration into global financial circuits (see Bassens et al., 2010a). Drawing on Shari'a Law, Islamic finance renounces all interest (riba), gambling (maysir) and contractual ambiguities (gharar) that lead to excessive risk taking. It also shies away from investment in certain 
products (e.g., pork meat, weaponry, alcohol, etc.) that are considered haram. Fundamentally, Islamic finance opposes the conventional debt-trading and promotes a system of profit-and-loss sharing (PLS) as the main regulatory mechanism of financial intermediation (Pollard and Samers, 2007). As was spelled-out elsewhere (Bassens et al., 2011a), the growth of Islamic finance was strongly fuelled by the combination of the Middle East oil boom and a broad reassertion of Islam in Muslim societies from the 1970s onward. Since then Islamic finance has been around, but it is only since the turn of the millennium that Islamic markets are expanding and globalizing rapidly - an evolution no doubt related to wider geo-economic shifts epitomized by the rise of emerging economies in 'the East' (Derudder et al., 2011, Taylor et al, 2009).

As Islamic markets 'mature', they are increasingly confronted with the need for financial products and mechanisms that enable Islamic financial institutions to operate on a global scale. In 'conventional' debt-based markets, assets-backed securities (ABS), mortgage-backed securities (MBS), collateralized debt obligations (CDO), and other products of structured finance have played a crucial role in integrating markets, mainly from the early 1980s onwards. According to Leyshon and Thrift (2007), the technique of securitization became popular for mainly three reasons. First, it allowed firms to access capital markets directly instead of receiving finance through bank loans. Second, large institutional investors such as pension funds were actively searching for products to diversify their portfolios. Third, and crucially, securitization was propelled by the financial sector's preoccupation to transfer liabilities off-balance. This enabled them to circumvent capital ratio's imposed by the Basel I and II agreements, which limited the size of outstanding loans vis-à-vis equity capital and thus the bank's ability to make profits and pay out bonuses (Aalbers et al., 2011). Crucially, the resulting products were increasingly being traded across the globe, creating deep and liquid secondary markets.

Islamic markets, on the other hand, are relatively young and illiquid. As they evolve and globalize, however, they seemingly relive evolutions that took place in debt-based markets. Like in 'conventional' markets disintermediation through securitization offers cheaper finance and longer maturity terms than bank loans. Islamic bankers and regulators are therefore actively looking for ways 
to build a more active (in terms of trade) and integrated market. There are, however, at least three idiosyncrasies that drive the demand for Islamic securitization. First, there is a pressing need for investment products - perhaps even more than in 'conventional' markets because of excess liquidity in key Islamic markets. Especially in the Gulf, oil-rich sovereign and private investors are looking for attractive investment products (e.g., securities, commodities, investment notes) with a Shari'acompliant character. These investors are either Islamic private financial institutions such as takaful (Islamic insurance) companies and investment funds, but also various oil-based sovereign wealth funds (SWFs), which are not 'Islamic' per se. For instance, the largest SWF in the Gulf, the Abu Dhabi Investment Authority (ADIA), has an estimated asset value of US\$875 billion (Behrendt, 2008). The mere size of these amassed assets has attracted international service firms, such as investment banks and law firms to the home-bases of this and other SWFs (e.g., Abu Dhabi, Doha, Dubai), in their attempt to capture a share of the business (Clark et al., 2010a). Second, the rapid growth of Gulf cities and related infrastructure and real estate developments is driving the need for finance products. These projects constitute an attractive market for regional and global investors (e.g., UK or American investment banks, see Bassens et al., 2010b) and serve as the feedstock for Islamic securitization chains. Third, Islamic intermediaries themselves are in urgent need for liquidity management (LM) tools, which could be found in securitization products. In the conventional system, banks can perform LM through short-term interest-bearing loans. Islamic banks, however, cannot access these debt-based markets (because of the riba prohibition) and the sector itself lacks a developed inter-bank market. Currently, LM mostly happens via the tawarruq mechanism at the London Stock Exchange, a hiyal (stratagem) whereby short-term lending is circumvented through the buying and on-the-spot selling of precious metals. Although this structure is Shari'a-compliant in form, it does not address the need for products and techniques that provide Shari'a-compliance in substance, thus reproducing the need for proper 'Islamic' techniques.

[Insert Figure 1 about here] 
In response to these caveats, financialization techniques such as Islamic securitization have emerged since the 1990s, resulting in an array of sukuk structures, which are basically Islamic asset-based or asset-backed investment notes (Jobst, 2007). These structures are increasingly connecting localized assets such as real estate projects in Gulf cities with global financial circuits. As illustrated in Figure 1, the global sukuk market has been growing at a steady pace since the turn of the millennium, both in terms of size and number of issuances, only to be withheld briefly during the 2008-2009 crisis. This temporary fall-back in itself illustrates the highly globalized nature of Islamic markets, with issuers suffering from low investment appetite at the time. However, this dip in sukuk issuance was also related to more 'local' events such as the Dubai debt crisis, which tipped off in 2009, almost leading to the default of Nakheel's US\$4 billion sukuk (Bassens et al., 2010b). Furthermore, as will be detailed below, the sukuk dip was also closely related to an existential crisis in the Islamic finance sector, triggered by the AAOIFI ${ }^{1}$ president Taqi Usmani fatwa on the non-Shari' a-compliant nature of most sukuk on the market. Recent issuance levels, however, are surpassing pre-crisis highs.

As per June 30, 2009 the total amount of outstanding sukuk equalled US\$136 billion (IIFM, 2010). Most of these sukuk, that is ca. US $\$ 101$ billion, are so-called 'domestic' issuances denominated in local currencies, aiming to attract investors at the national or regional scale. The other US\$35 billion, however, are 'international', mostly dollar-denominated designed to attract investors from outside the national or regional realm. This global investor break-down suggests that sukuk are gaining popularity, not only with Muslim investors, but also with non-Muslim investors who seek to diversify their investment portfolios. As illustrated in Table 1, Malaysia is dominating domestic issuance, while the Gulf is leading the way in terms of international sukuk. For reasons of Shari'a-compliance, which favours investment in the 'real' economy, sukuk finance in both regions has an intimate link with 'tangible' assets, either in real estate and property development, large infrastructure works

\footnotetext{
${ }^{1}$ The Bahrain-based Accounting and Auditing Organization for Islamic Financial Institutions (AAOIFI) is one of the most influential standard-setting regulatory bodies for Islamic financial institutions. These standards include (i) accounting and auditing rules; (ii) Shari' a governance rules; (iii) a code of ethics for financial auditors and employees; and (iv) standards concerning the actual financial practices, products, investments, etc. that fall under the concepts of Islamic banking, finance, and insurance (see website AAOIFI, http://www.aaoifi.com, accessed May 26, 2011).
} 
(highways), industrial infrastructure (petrochemical sector), or infrastructure with a focus on building global connectivity (e.g., airlines, port operations, etc.).

[Insert Table 1 about here]

To further deepen our understanding of sukuk markets, we have collected key information on 269 maturing sukuk (due December 2009 or later), with an approximate total value of US\$117 billion. The data set has been comprised by scanning various data sources, such as websites of Islamic securities exchanges, Islamic regulatory bodies, and others. We have screened all major exchanges in the Muslim world and prominent global exchanges involved in Islamic finance. This resulted in a relatively small number of exchanges that list Islamic products, namely Dubai Financial Market, Nasdaq Dubai, Labuan Financial Exchange, London Stock Exchange, Luxembourg Stock Exchange, Bahrain Stock Exchange, Dow Jones, and Tadawul Riyadh. Since a lot of the outstanding sukuk are not listed, we have broadened the scope of the data set with additional info provided by Islamic regulators, such as sukuk approved by the Securities Commission (Malaysia), or which have been arranged by Liquidity Management Centre (Bahrain). In addition, extra data were collected from private market analysts such as Bloomberg (www.bloomberg.com), Failaka Advisors (www.failaka.com), Zawya (www.zawya.com), and promotional agencies such as the Al Huda Center of Islamic Banking and Finance (www.alhudacibe.com), based in Pakistan. Although not exhaustive, the range of sources used, guarantees a detailed and 'global' overview of sukuk issuance. In many cases detailed information on individual issuances, such as activities and location of the seller and the bank(s) that arranged the sukuk, could be retrieved from investment circulars.

[Insert Table 2 about here]

As illustrated in Table 2, the resulting data set contains information on the nature of the financed projects, the identity of the seller, the arranger/manager of the issuance (e.g., global banks or regional Islamic banks), and the place of listing on international markets. Reviewing the entire data set 
produced further insight in the geographical market differences between the two heartlands of sukuk issuance, Malaysia and the Gulf. In Malaysia, sukuk are often state-based initiatives to finance these large infrastructural works through national investments in ringgit-denominated sukuk. While this is also true for the Gulf, with sukuk used to attract domestic oil-money via dirham- or riyalsdenominated products, dollar-denominated sukuk are used as a vehicle to attract international investors via listings on regional and international exchanges. When it comes to the actors involved in the structuring process, most Malaysian issuances are arranged and managed by domestic banks such as CIMB, Aseambankers, Bank Muamalat Berhad, and others. In the Gulf, on the other hand, issuance is often co-managed by Gulf-based Islamic banks - Bahrain Islamic Bank, Emirates NBD, Dubai Islamic Bank, Gulf Finance House, Kuwait Finance House, Al Rahji Bank, Noor Islamic Bank, etc. and large international banks such as Barclays, Deutsche Bank, HSBC, Standard Chartered, JP Morgan, and Citigroup. Second, also in terms of listing there are marked differences. Malaysian sukuk are mostly traded bilaterally in Over-The-Counter (OTC) markets and hence rarely listed. Gulf sukuk, on the other hand, are frequently listed on international exchanges such as Bahrain, Nasdaq Dubai, LSE, Luxembourg SE, Tadawul, etc. These listings, however, do not imply active trading since most sukuk are held until maturity, making secondary markets illiquid to almost non-existent. The existence of such spatial variegation in sukuk markets is closely related to the geo-historical evolution of Islamic securitization itself, a topic to which we turn in the next section.

\section{A geo-historical account of Islamic securitization}

The overview in the previous section has banned the possible misconception of viewing the sukuk market as a robust and well-integrated 'entity'. In fact quite the contrary is actually the case: Not only do sukuk markets show intense geographical variegation, they also vary greatly in terms of underlying contracts. As defined by Article 2 of AAOIFI's Shari'a standards, sukuk are "certificates of equal value representing undivided shares in ownership of tangible assets, usufruct and services or (in the ownership of) the assets of particular projects or special investment activity". In practice this definition is more a rule of thumb than a crisp legal constraint, since very few issued sukuk actually live up to this definition. According to Shari'a scholar Mohammad Daud Bakar (2010) sukuk can be 
broadly divided in four categories, depending on their product design, product offering, pay off to investors, and rating methodology, which contrast with the above-suggested uniformity. They can be identified as either: (i) debt-based; (ii) asset-based; (iii) project-based; or (iv) asset-backed sukuk. Chronologically, there has been a general trend away from the first debt-based category, towards the latter, with asset-backed securitization as the most recent innovation in the field of Islamic securitization. With each new step, the assets that underlie the structure gain importance in terms of being the actual source of revenue for the sukuk investors.

[Insert Figure 2 about here]

Figure 2 provides a brief overview of how sukuk markets have evolved since the early 1990s, and how this 'travel log' was accompanied by geographical dispersal. Sukuk have evolved gradually to comprise a vast and variegated array of products that vary in terms of structure, securitized assets, and underlying contracts. A first and crucial development for the opening-up of Islamic markets to securitization was the decision of the Jeddah-based Islamic Fiqh Academy in 1988 that assets could to be bundled and represented by a bond, which could then be sold at market price, provided "the group of assets, represented by the security, consists of a majority of physical assets and financial rights, with only a minority being cash and interpersonal debts" (www.fiqhacademy.org, accessed September 20, 2010). Islamic markets, however, only gradually opened-up to securitization following the blessing of the influential voices of Shari'a scholars at the Fiqh Academy. Not the Gulf Region, but Malaysia, which is usually considered more lenient in its interpretation of Shari'a Law, was the first to experience the introduction of securitization. The first sukuk were issued there in 1990 by Shell MDS (also Global Oil Corp.) and were structured as Islamic debt of RM125 million (ca. US\$30 million) based on receivables securitization (bai' bithamin ajil, BBA) (Thomas et al., 2005, 159). The structure consisted of a deferred payment sale at a pre-agreed price with a profit margin agreed by both parties, which made it in essence a mark-up product similar to a conventional bond. Soon after this pioneering issuance the Malaysian market saw the growth of similar corporate Islamic debt 
structures. As in conventional interest-based markets, Islamic markets have been generally established through sovereign sukuk, which could then be used as a benchmark for corporate issuances.

From Malaysia, sukuk securitization spread to Gulf Islamic markets, and was gradually introduced from 2001 onward via sovereign issuances in Bahrain (Bahrain Monetary Agency, 2001) and Qatar (Qatar Global sukuk, 2002), later followed by (quasi-)sovereign and corporate issuances in the UAE and Saudi Arabia (Wilson, 2004). Notwithstanding their success in Malaysian markets, debt-based structures such as BBA were considered unacceptable in the Gulf because of their similarities with debt-based bonds. As they entered Gulf markets, sukuk had to accommodate to stricter Shari'a interpretations and were actively moulded by the teams of lawyers and bankers that structured the deals. This was because while the contracts proper that underpin debt-based structures were considered Shari'a-compliant (e.g., murabahah (cost-plus financing), ijarah (lease), or istisna'a (manufacturing contract)), the overarching sukuk structure was not, since the investors receive fixed payments that originate from the underlying contracts. Mainly from 2006 onwards, then, two 'innovations' have been introduced in Islamic markets to structure sukuk more according to the profitand-loss-sharing principle, rather than using sukuk as a formal way to circumvent the Shari'a ban on debt-selling. These are project-based sukuk and 'classic' asset-backed securitization (ABS) structures. Both structures involve 'true securitization', without a fixed pay or no guaranteed return at the time of dissolution. In case of project-based sukuk the underlying contract is generally an istisna'a (manufacturing contract) or musharakah (diminishing partnership), and the pay-off to investors is to a degree related to the performance of the underlying assets. In asset-backed sukuk, which are usually based on mudarabah (passive partnership) or musharakah structures, the performance of sukuk is entirely linked to the real value and risk of the underlying assets (Daud Bakar, 2010), thus being completely in line with the PLS principle. Ironically, however, the Dubai debt crisis has shown that even real assets can be the object of intense speculation, making the build-on financial instruments equally speculative. Moreover, notwithstanding the discussed geo-historical developments towards true ABS, the most common (although also controversial) securitization technique in globalized Gulf 
markets still involves selling assets to a special purpose vehicle (SPV) and leasing them back via a socalled sukuk al-ijara - a technique that we will discuss in more depth in the next section.

Lately, sukuk have also started to contribute to the further integration of Islamic markets at a global scale as sukuk structures are being exported to fit the demands of non-Muslim entities that wish to attract Gulf investments. In this context there have been a few 'special issuances' by corporate and sovereign bodies, such as the government of Saxony-Anhalt (2004), General Electric (2009), and International Finance Corporation $(2004,2009)$. These Islamic structures are likely to undergo a second round of adaptations to fit the regulatory regimes of non-Islamic markets. Given the budget problems in 'developed' economies at the moment, however, these issuances are unlikely to be the final instalment in the story of Islamic securitization.

\section{The case of Emaar Sukuk Limited}

Here we present a case-study of the above-mentioned Emaar Sukuk Limited, a recent international sukuk that aptly illustrates the globalized nature of Islamic securitization markets. The sukuk emitted by the Dubai-based Emaar Properties PJSC were launched on February ${ }^{\text {rd }}$, 2011 via the LSE for a total value of US\$500 million as a first series of a larger issuance of US\$2 billion. Emaar, partially owned by the Dubai government (ca. 32\%) has been one of the main property developers in the emirate, which has constructed the gargantuan Burj Khalifa (formerly known as Burj Dubai), and which also has operations throughout the Middle East, North Africa, China, India, and Northern America. Since the inception of the global financial crisis and further augmented by the collapse of the Dubai real estate market in 2009, Emaar has found itself in rough seas, seeing its yearly profits melting away from annual levels of US\$6,5 million in 2007 to US\$0,3 million in 2009 (Financial Statements, downloaded from www.emaar.com, May $\left.24^{\text {th }}, 2011\right)$. Emaar was thus in urgent need for fresh investor money to offset losses and diversify away from the Dubai real estate market. Through this issuance Emaar has managed to raise the targeted US\$500 million, which understates the success of the sukuk since they were oversubscribed more than three times (US\$1.7 billion), echoing the success of pre-crisis issuances arising from the Gulf - a sign that investor confidence towards Dubai is apparently restored. 
[Insert Figure 3 about here]

Figure 3, which we retrieved from the issuance prospectus (downloaded from www.londonstockexchange.com, May $\left.20^{\text {th }}, 2011\right)$, presents a basic and highly simplified view of the underlying securitization structure. In essence the structure presented here is centred on an ijarah saleand-lease-back operation, between the obligor Emaar Properties PJSC which sells assets to a bankruptcy-proof SPV, the issuer Emaar Sukuk Limited, which issues sukuk and sells them to the endinvestors (the sukuk holders) to purchase these assets. After this initial sale, Emaar Properties PJSC (lessee) leases the sold assets from the SPV (lessor), generating a cash-flow which is channelled to the certificate holders. When the sukuk mature, the assets are bought back by the obligor and this amount is used to repay the principal amount to the investors. The simplicity and transparency suggested by this securitization structure, however, greatly obscures the multiplicity of actors and institutions involved in the securitization process, and understate the complexity of the multiscalar networks producing and operating even such 'basic' a sukuk structure. Figure 4, therefore aims to provide what is admittedly still a simplified overview of the global geographies of such multilayered securitization networks, in this case geared towards the Emaar sukuk.

[Insert Figure 4 about here]

As shown in figure 4 a first type of networks revolves around the structuring of the deal, reflecting the geographies of the obligor, the issuer and the investment banks that have arranged the deal. Although it entails a Dubai-based company, the legal entity issuing the sukuk, the SPV called Emaar Sukuk Limited, is registered on the Cayman Islands to reap the benefits of off-shoring. The deal itself is arranged from London from the offices of HSBC, Standard Chartered, The Royal Bank of Scotland, and Dubai Islamic Bank operating from Dubai. The structuring process is screened in terms of Shari'a-compliance by HSBC in-house 'Central Shari'a Committee' and Standard Chartered's 'Shari'a Supervisory Committee'. The screening by two teams consisting of three Shari'a scholars each no doubt instils investor confidence in the Shari'a-compliance of the sukuk. However, a closer 
look at the boards' constitution reveals that the screening actually involves only four scholars, of whom two are sitting on both boards. This situation echoes broader trends of Shari'a board interlocking, which have been identified as potential means for Shari'a standard setting at the level of financial institutions themselves (Bassens et al., 2011b).

A second set of networks supports the management of the sukuk structure. The first 'role' involves the ownership and administration of the issuing SPV. The management thereof is not provided by the obligor Emaar Properties, but rather by a licensed trust company called Maples Finance Limited, which is operating from the Cayman Islands. As in conventional securitization, this means that securitization requires a so-called trust deed, which implies a transfer of title to a trustee (in this case Maples Finance Limited), which will hold it as a security for the investors. In common law jurisdictions this particular construction enables the parties to enjoy the benefits of off-shoring, while limiting the recourse of investors to the assets itself. However, whereas the above is similar to conventional securitization, the particularities of Islamic securitization have generated the need for an entirely new role. From a conventional perspective, Islamic structures would require the SPV not only to act as the issuer of sukuk, but also as a trustee holding the underlying assets on trust for the certificate holders. This has led to the creation the role of a 'delegate', who is responsible for holding the assets. This role is again fulfilled by a trust company, in this case the London-based HSBC Corporate Trustee Company (UK) Limited.

This leads us to consider a third type of networks, namely those reflecting the networks that link up sukuk with (potential) investors. One way to attract investors is via a listing of the sukuk at an official stock exchange. To get listed at the LSE for example, as is the case of Emaar Sukuk Limited, the structured products need to be rated by at least two rating agents. Here ratings were provided by Moody's (B1) and Standard and Poor's (BB), who have both identified them as high-risk junk bonds. To instil investor confidence a reliable auditor (in this case Ernst \& Young, Dubai) is involved in providing the necessary documentation for the issuance, such as the sukuk prospectus itself, which includes the financial statements of the obligor Emaar Properties. Most sukuk investment, however, is emitted and traded bilaterally in so-called Over-The-Counter (OTC) markets, which necessitates the 
use of interdealer-brokers as mediators between sellers and buyers. Such brokers usually buy an entire series of trust certificates and may then decide to sell them to end-investors. In this case the brokers were located in London (BNP Paribas, HSBC Bank, Merrill Lynch International, The Royal Bank of Scotland), Dubai (Standard Chartered Bank), and Singapore (DBS Bank), which illustrates the global investment breakdown for these particular sukuk: European investors accounted for $52 \%$ of the transaction, while Middle East, Asian and US (offshore) investors accounted for 38\%, 7\% and 3\%, respectively, of the issuance. In terms of investor type, the offering was distributed as follows: $60 \%$ for Fund Managers, 29\% for Banks, 8\% for Private Banks and 3\% for Insurance Companies (Dubai Chronicle, 2011). Once the connection with investors is made, further servicing involves the registration of the certificate holders (registrar), the calculation of payments (calculation agent), and making payment to the investors (principal paying agent and transfer agent). In this case all tasks are performed by HSBC Bank (London) where the sukuk are listed.

Fourth and finally, the entire process also requires intense interaction with networks of legal firms who provide knowledge of the multiple jurisdictions being crosscut by the securitization chain, even though the overarching structure itself falls under English and UAE law. In this case this means that knowledge (i) of UAE and English law is provided by Allen \& Overy and Linklaters (both based in Dubai International Financial Centre, DIFC) to the obligor (and also to the brokers in case of Allen \& Overy), (ii) of Cayman Islands law is provided by Maples and Calder (also from the DIFC) to the issuer, and (iii) of English law is provided Allen \& Overy (from their London office) to the sukuk delegate in London.

Overall, the case of Emaar Sukuk Limited highlights the interlocking of Gulf sukuk markets with 'conventional' institutions, operating from mainstay International/Offshore Financial Centres (IFC/OFCs). ${ }^{2}$ While this can be read as a straightforward illustration of the intense globalization of Islamic securitization markets, the transnational financial space sustained by such interconnectedness also serves as a platform for transplantation of financial techniques, ideologies, cultures, practices,

\footnotetext{
${ }^{2}$ See Palan et al., 2010 for the argument that many IFCs double as OFCs and in fact provide financial firms with a double coded jurisdiction.
} 
and discourses. This transplantation is the result of the actions of financial elites, who can wield a set of conventional structured finance techniques, which they mutatis mutandis deploy to capture new and profitable markets. Seemingly sukuk structuring teams are borrowing the blueprint of securitization techniques originating in 'conventional' markets, and are using it as a panacea to find existing or innovate ways around Islamic prohibitions to build Shari'a-compliant products. Indeed, as we will argue in the next section, the above-sketched geographies of 'entanglement' (Callon, 1998; Maurer, 2005) involve a large degree of 'mimicking' of conventional structuring techniques (Khan, 2010).

\section{Discussion: Differences and similarities with 'conventional' securitization structures}

These processes of transplantation and mimicking become visible when we compare the Emaar Sukuk structure (Figure 3) with a typical handbook Anglo-American securitization. Of course, as illustrated above, sukuk securitization is characterized by particularities at various points of the securitization chain: (i) the structuring process requires screening by Shari'a scholars to verify the Shari'acompliance of the sukuk; (ii) the management of the structure requires the introduction of a 'delegate', charged with the management of the securitized assets; (iii) sukuk investments are made by conventional investors and Islamic investors, both from mainstay and emerging IFC/OFCs; and (iv) sukuk structures require operating in multiple legal jurisdictions, some of which are not governed by English law (e.g., UAE law). A superficial glance at the prospectus, however, shows that it is in fact very similar to a 'conventional' prospectus, featuring most of the usual terminology, notices to residents of various countries explaining their non-eligibility as investors, terms and conditions of the certificates, financial information of the obligor, etc. There are some differences, however, including a very transparent and elaborate discussion of the investment risks, which make reference to the risks linked to investing in emerging markets. However, when we skate over these superficial differences and dig deeper into the actual contractual structures supporting the issuance, it becomes obvious that sukuk are essentially very similar to 'conventional' debt-based structures such as bonds, but also vary significantly from structured finance products based on the securitization of income flows known from their role in the recent crisis (see Figure 5). 
[Insert Figure 5 about here]

This is because the structure of the securitization itself is much simpler than in conventional products such as RMBS. For instance, there is no mention of waterfalling or tranching that provides investors with different classes of bonds (equity, mezzanine, senior and super senior tranches) with different credit risk ratings and different interest rates. This overt simplicity strongly suggests that the technique of securitizing assets is used here as a mere stratagem to circumvent Shari'a rules, as they are 'Islamic' in form, but not in substance (Agha, 2009). This can be deduced from three observations.

First, in common asset-based structures certificate holders do not receive periodic payments on a variable profit-and-loss sharing basis, but instead receive a fixed interest rate that is often benchmarked to LIBOR (London Interbank Offered Rate). As for the Emaar sukuk, the trust certificates indeed return a fixed yield of $8.5 \%$, which makes the revenue for investors completely detached from the performance of the underlying assets. As with conventional debt-based products, then, it is the rating of the seller and not the assets that determines the sukuk rating. This explains why, contrary to a prospectus of 'conventional' securitizations where the emphasis is on the underlying assets, sukuk prospectuses extensively detail the credit status and the background of the obligor. In this case, the obligor Emaar Properties is partially government-owned, which makes that its rating is linked to the overall creditworthiness of the Emirate of Dubai, which is precarious at the moment. Second, the agreement of purchase undertaking (PU) included in the contract, which binds the seller to repurchase the assets at maturity, guarantees the investments of the sukuk holders disregarding the actual performance or value of the underlying assets, and thus violates the PLS principle. Third, in asset-based structures such as the above no 'true' sale occurs, but rather a transfer to the issuer of a collection of 'rights akin to ownership' that allows the issuer to issue sukuk and enables the investor to participate in the revenues generated by the underlying assets. This means that investors have no recourse to assets, making the Emaar sukuk in fact unsecured obligations, which also explains the fixed interest rate paid on the notes. This limited recourse to underlying assets reflects the fact that non-residents are more than often not allowed to own or lease these Gulf assets 
(Thomas et al., 2005, 158), which explains why until recently the ijarah approach was usually sufficient to satisfy Shari'a scholars. In November 2007 Taqi Usmani, the president of AAOIFI's Shari'a Board has voiced the critique that sukuk are, in fact, nothing more than conventional debt. As the recent Emaar issuance, however, illustrates this critique has fallen on deaf ears with Islamic finance professionals and their Western handmaidens.

How should we then interpret these similarities and idiosyncrasies of sukuk securitization? Do they suggest an unstoppable convergence towards an Anglo-American norm of financial modernity or do they project a mode of financial modernization whose modi operandi remain entangled in the requirements of Islamic traditionalism? Or do they instead suggest a complex negotiation of Islamic elites between development and cultural preservation resulting in unintended, undesigned sociotechnical hybrids with uncertain future paths of further development (Yeung 2004)? To answer this question we can consult a growing number of studies that have been conducted in organizational sociology around the concept of 'organizational mimicry' or 'mimetic isomorphism'. These concepts were minted in the early 1980s by DiMaggio and Powell to capture the observation that organizations tend to imitate organizational models, management techniques and administrative technologies ascribed to reputational leaders within (and across) specific organizational fields in an attempt to 'follow' and surpass the leader (DiMaggio and Powell, 1983). In their conception, organizational intentions were empirically often observed to be constrained by positional and contextual dissimilarities between 'leader' and 'follower', resulting in unintended outcomes and hybrid assemblages of the old and the new, the local and the global, the vernacular and the universal.

Similar processes can be observed in our case, where Anglo-American techniques of securitization serve as a dominant, hegemonic template for mimicry by organizations at the boundaries of the dominant field. This mimicry operates both at the level of particular techniques as at the level of context itself. To begin with the latter, in many instances the environment too requires subtle changes to become more similar to the original environment and allow these socio-technical assemblages to function properly, where what is 'proper' is defined by elites circulating in bridging networks. The 
adaptation of context is most evident from the emergence of a dotted geography of local 'islands' operating under the banner of common law legal frameworks (e.g., the Dubai International Financial Centre), which has allowed some Gulf cities to become nodes in global financial circuits that reproduce UK/US based legal systems off shore. Turning to the changes of financial techniques themselves, it appears that instead of beginning with a tabula rasa, Islamic securitization draws on techniques originating elsewhere that are redeployed and then undergo context-sensitive redevelopment. These contextual constraints and incentives emerge from economic factors, such as high oil liquidity and the need for mechanisms to finance the urban boom, as well as social, cultural, and religious factors grounded in a general reassertion of Shari'a-compliant discourses.

Since Islamic financiers are mainly mirroring models that have originated in Anglo-American markets instead of the other way round, mimetic processes in Islamic markets are asymmetric, notwithstanding the willingness of Western firms and investors to tap into Islamic circuits of capital. This receptiveness to 'foreign' models in Islamic markets can be understood from the crucial role of analogy and consensus-building in the case-based formation of legal opinions of Shari'a scholars. This disposition has produced Islamic markets that are strongly marked by rent-seeking first-movers, who are stretching Shari'a rules to fit new and profitable fields such as Islamic securitization, but lately also Islamic credit cards and hedge funds, which seem Shari'a compliant but fundamentally violate 'Islamic' bans on interest, speculation, and excessive risk-taking. This does, however, not imply that mimicry happens in a 'blind' and straightforward fashion, as is suggested by classic stageist modernization narratives (Kerr, 1960; Parsons, 1966; Rostow, 1960; see critically Sheppard, 2011). Rather, as was illustrated by the geo-historical account of Islamic securitization, these negotiations happen gradually and follow a 'trial-and-error'-logic, thus constituting a complex and iterative process that echoes the kind of 'bricolage' discussed by Engelen et al. (2010) in the context of an analysis of the 'securitization' machine that wrecked Anglo-American finance in the recent crisis. 
However, in terms of outcomes, we depart from the 'isomorphism' that DiMaggio and Powell postulate as the telos of mimicry, contending that their homogenizing viewpoint reflected a time (the early 1980s) when scholarly sensitivity to the durability of hybrid effects and outcomes was still in the process of gestation. In fact, the concept of hybridity only moved from evolutionary biology to the social sciences in the mid 1990s, suggesting a gradual departure from the homogenizing assumptions underlying modernization theory (Steinmetz, 2005). While we have demonstrated that mechanisms of homogenization are indeed at work in Islamic finance, they do not necessarily lead to isomorphism per se. Indeed, in Islamic securitization markets putatively similar tools and stratagems are used notably the technique of off-shoring via a SPV which is the crux of securitization - but the aims of their employment move beyond the 'regulatory arbitrage' that is behind 'conventional' securitization markets. Rather, it appears that these exact same techniques are being used to circumvent regulations of Shari' a-compliance, thus leading to forms of 'religious arbitrage' instead (see El-Gamal, 2006).

In sum, the above account of Islamic securitization suggests, counter to images of 'empire-like' neocolonization that straightforwardly leads to increased homogenization, the emergence of hybrid outcomes. These are mediated not only by financial elites employed by banks and service firms operating from 'global cities' and IFCs, but also mediated by 'local' financial actors such as Shari'a scholars, Islamic bankers, trust managers, regulatory bodies, and others operating from 'local' financial centres. Backed by religious authority and the power of substantive financial leverage (petrodollars), these local power brokers act as emerging markets' 'gatekeepers', bridging and connecting metropolitan and peripheral networks and circuits, and through their trial-and-error negotiations co-producing something that to the outsider appears as financial integration and for the insider feels as opportunistic bricolage (Bassens et al., 2012; Engelen et al., 2010).

\section{Implications for economic geography}

The case-study presented here illustrates how global finance, its narratives, discourses, techniques, and agents, is fundamentally plural. As securitization diffuses through the social pipelines that undergird financial markets and is, through processes of organizational mimicry, introduced in new 
contexts, the technique, structure, aims, and perceptions of securitization are simultaneously reproduced and altered to serve new contextual goals: religious arbitrage instead of regulatory arbitrage, dodging religious commandments rather than the prescripts of the central bank. This implies that while global finance unmistakably refers back to global discourses and practices, which crosscut national boundaries and transcend regulatory regimes, local and regional institutional variegation still influences and shapes the practice of global finance (Clark, 2005). Therefore, as Clark et al. (2010b, 3) have recently argued, "[...] understanding the evolving economic landscape of twenty-first century capitalism will rely crucially on understanding the global and local practices and variegated institutional configurations of finance".

While we fully endorse this view, we take the opportunity here to deduce a number of suggestions from our case study for future geographical investigations of the variegated and financialized capitalisms of today and tomorrow. For one there is a pressing need to come to grips with the plurality of finance in what the World Bank has recently called a 'multipolar world' (World Bank, 2011), marked by the absence of a hegemon that possesses the power to enforce upon societies elsewhere its visions of the future, either through hard or soft power (Nye, 2004). As the World Bank report sketches with regard to monetary policies, suggesting a multicurrency world instead of a world that is dominated by the dollar, our case study too suggests a future of multiple jurisdictions that are increasingly vertically linked, allowing for multiple negotiations of financial agents across the boundaries of those jurisdictions, resulting in highly uneven forms of financial 'bricolage' that break with the simple core-periphery logic that underlies notions of isomorphism and its absence. This means that we need to reconceptualise the world of finance as an increasingly symmetrical field where the ability of agents to set the norm is not determined by country of origin, but by market reputation that might not survive the next crisis. In a flagrant break with Economics 101 textbooks, our case demonstrates that there is no pure form of securitization. Instead there are different regional, national and even local variations, which use seemingly similar techniques to slightly different ends.

As our case study suggest, then, there is a pressing need to go beyond the hidden assumptions of modernization theory writ large which are especially dominant in the discipline of economics, with its 
pretension of academic neutrality, its positivist ethos and its claim to universal law-like generalizations. Engaging with economics, as is the remit of this journal (Arnott and Wrigley, 2001; Wrigley and Overman, 2010), could easily seduce geographers to forget the humbling lessons from earlier engagements with the other social sciences. These were lessons of self-reflexivity, complexity, conditional causation and a world that largely escapes quantification and modeling. On the back of this we want to close with hesitantly raising the question whether an ongoing engagement with economics is worth the effort if it requires geographers to endorse its assumptions and mimic its ethos. For not only has it been a one way dialogue - from geography to economics with not much talking back from economists, as has been ruefully noted on a number of occasions in this journal (Brakman et al., 2011; Garretsen and Martin, 2011; Wrigley and Overman, 2010) - the crisis too has indicated an urgent need on the side of academic economics to revisit some of its deeply buried core postulates: from its conceptualization of agency to its notion of markets to its empiricist philosophy of science to its politics of top down engineering. We confess to a certain disaffection with the asymmetrical project of gaining the ear of economists. Instead, we would like to suggest to broaden the conversation again and invite cultural anthropologists, organizational sociologists, political scientists (back) to the table - as well as those economists that have demonstrated to put empirical complexity above paradigmatic parsimony (mostly those working in slightly 'tacky' subfields like labor or developmental economics (see Card and Krueger, 1995; Rodrik, 2008). Indeed, if the crisis has taught us anything it is that we neglect the fact of social complexity at our own peril. That is a lesson that comes easier to geographers than economists.

\section{Acknowledgements}

This work was supported by the Research Foundation - Flanders [Grant No. 3G066408]. We thank Anna Glasmacher for pointing out discrepancies between Islamic and 'conventional' securitization techniques. Further, we also thank two anonymous referees for their insightful comments on earlier versions of this paper. Evidently, we are responsible for all remaining errors.

\section{References}


Aalbers, M., Engelen, E., Glasmacher, A. (2011) Mortgage Securitization and the State: 'Cognitive Closure' in the Netherlands. Environment and Planning A, 43 (8), 1179-1795.

Agha, O. (2009) Islamic finance: Principle before profit. Berkeley Journal of Middle Eastern Islamic Law, 2 (1): 125-135.

Albertazzi, U., Eramo, G., Gambacorta, L., Salleo, C. (2011) Securitization is not that evil after all. BIS Working Papers no. 341.

Appadurai, A. (1996) Modernity at Large: Cultural Dimensions of Globalization. Minneapolis: University of Minnesota Press.

Arnott, R, Wrigley, N. (2001) Editorial. Journal of Economic Geography, 1 (1): 1-4.

Bassens, D., Derudder, B., Witlox, F. (2010a) Searching for the Mecca of finance: Islamic financial services and the world city network. Area, 42 (1): 35-46.

Bassens, D., Derudder, B., Witlox, F. (2010b) The making and breaking of Dubai: the end of a citystate? Political Geography, 32 (6): 299-301.

Bassens, D., Derudder, B., Witlox, F. (2011a) Oiling global capital accumulation: analyzing the principles, practices and geographical distribution of Islamic financial services. Service Industries Journal, 31 (3): 327-341.

Bassens, D., Derudder, B., Witlox, F. (2011b) Setting Shari'a standards: on the role, power and spatialities of interlocking Shari'a boards in Islamic financial services. Geoforum, 42 (1): 94-103.

Bassens, D., Derudder, B., Witlox, F. (2012) 'Gatekeepers' of Islamic financial circuits: analyzing urban geographies of the global Shari'a elite. Entrepreneurship and Regional Development, published online, doi: 10.1080/08985626.2011.577820.

Beaverstock, J. V., Faulconbridge, J., Hall, S. J. E. (2010) Professionalization, legitimization and the creation of executive search markets in Europe. Journal of Economic Geography, 10 (6): 825-843.

Behrendt, S. (2008) When money talks: Arab sovereign wealth funds in the global public policy discourse. Carnegie papers from Carnegie Middle East Centre, 12. Washington DC: Carnegie Endowment for International Peace.

Brakman, S., Garretsen, H., van Marrewijk, C. (2011) References across the fence: measuring the dialogue between economists and geographers. Journal of Economic Geography, 11 (2): 371-385.

Brenner, N., Peck, J., Theodore, N. (2010) Variegated neoliberalization: geographies, modalities, pathways. Global Networks, 10 (2): 182-222.

Callon, M. (1998) Introduction: the embeddedness of economic markets in economics. In The laws of the markets, M. Callon (Ed.): 1-57, Oxford: Blackwell.

Card, D, Krueger, A. (1995) Myth and Measurement: The New Economics of The Minimum Wage. Princeton: Princeton University Press.

Clark, G. L. (2005) Money flows like mercury: the geography of global finance. Geografiska Annaler Series B - Human Geography, 87B (2): 99-112.

Clark, G. L., Dixon, A. D., Monk, A. H. B. (2010b) Introduction. In Managing Financial Risks: From Global to Local, G. L Clark, A. D. Dixon, A. H. B. Monk (Eds.): 1-23, Oxford: Oxford University Press.

Clark, G. L., Monk, A., Dixon, A., Pauly, L. W., Faulconbridge, J., Yeung, H. W. C., Behrendt, S. (2010a) Symposium: sovereign fund capitalism. Environment and Planning A, 42 (9): 2271-2291.

Daud Bakar, M. (2010) Sukuk structures. Retrieved September 8, 2010, from http://www.zawya.com.

Derudder, B., Hoyler, M, Taylor, P. J. (2011) Goodbye Reykjavik: international banking centres and the global financial crisis. Area, 43 (2), 173-182.

DiMaggio, P. J., Powell, W. W. (1983) The iron cage revisited: Institutional isomorphism and collective rationality in organizational fields. American Sociological Review, 48 (2): 147-160.

Djelic, M.-L. (1998) Exporting the American model: the post-war transformation of European business. Oxford: Oxford University Press. 
Djelic, M.-L., Quack, S. (2007) Overcoming path dependency: path generation in open systems. Theory \& Society, 36 (2): 161-186

Dubai Chronicle (2011) Emaar successfully executes first international fixed-income offering of US $\$ 500$ million, www.dubaichronicle.com, accessed online May $31^{\text {st }} 2011$.

Eisenstadt, S. N. (2000) Multiple Modernities. Daedalus, 129 (1): 1-29.

El-Gamal, M. A. (2006) Islamic Finance: Law, Economics, and Practice. New York: Cambridge University Press.

Engelen, E., Erturk, I., Froud, J., Leaver, A., Williams, K. (2010) Reconceptualizing financial innovation: frame, conjuncture and bricolage. Economy and Society, 39 (1): 33-63.

Faulconbridge, J. R., Muzio, D. (2009) The financialization of large law firms: situated discourses and practices of reorganization. Journal of Economic Geography, 9 (5): 641-661.

Frankel, A., Gyntelberg, J., Kjeldsen, K., Persson, M., (2004) The Danish Mortgage Market. BIS Quarterly Review March 2004.

FT (2011) Emaar seeks to ease debt with \$500m bond, www.ft.com, accessed online May $20^{\text {th }} 2011$.

Garretsen, H., Martin, R. (2011) The Journal of Economic Geography a decade on: where do we go from here? Journal of Economic Geography, 11 (2), 207-213.

Hall, S. (2006) What Counts? Exploring the production of quantitative financial narratives in London's corporate finance industry. Journal of Economic Geography, 6 (5): 661-678.

Hall, S. (2008) Geographies of business education: MBA programmes, reflexive business schools and the cultural circuit of capital. Transactions of the Institute of British Geographers, 33 (1): 27-41.

Hall, S., Appleyard, L. (2009) 'City of London, city of learning?' Placing business education within the geographies of finance. Journal of Economic Geography, 9 (5): 597-617.

Hassan, M., Dridi, J. (2010) The Effects of the Global Crisis on Islamic and Conventional Banks: A Comparative Study. IMF Working Paper 10/201.

IIFM (2010) Sukuk report: a comprehensive study of the international sukuk market. Retrieved September 15, 2010, from http://www.iifm.net.

Jobst, A. A. (2007) The Economics of Islamic Finance and Securitization. IMF Working Paper $07 / 117$.

Jobst, A. A. (2008) Back to basics - What is securitization? Finance \& development, 45 (3): 48-49.

Kerr, A. (1960) Industrialism and Industrial Man. Cambridge: Harvard University Press.

Khan, F. (2010) How 'Islamic' is Islamic Banking? Journal of Economic Behaviour \& Organization, $76(3), 805-820$.

Knauft, B. (Ed.) (2002) Critically Modern: Alternatives, Alterities, Anthropologies. Bloomington: Indiana University Press.

Lai, K. P. Y. (2006) 'Imagineering' Asian emerging markets: financial knowledge networks in the fund management industry. Geoforum, 37: 627-642.

Leyshon, A., Thrift, N. (2007) The capitalization of almost everything: the future of finance and capitalism. Theory, Culture, and Society, 24 (7-8): 97-115.

Maurer, B. (2005) Mutual Life, Limited: Islamic Banking, Alternative Currencies, Lateral Reason. New Jersey: Princeton University Press.

Nye, J. (2004) Soft Power: The Means to Success in the World. Washington: Foreign Affairs.

Palan, R., Murphy, R., Chavagneux, C. (2010) Tax Havens: How Globalization Really Works. Ithaca: Cornell University Press.

Parsons, T (1966) Societies: Evolutionary and Comparative Perspectives. London: Prentice Hall.

Pieterse, J. N. (2000) After post-development. Third World Quarterly, 21 (2): 175-191.

Pollard, J., Samers, M. (2007) Islamic banking and finance: postcolonial political economy and the decentring of economic geography. Transactions of the Institute of British Geographers, 32 (3): 313-330. 
Rajapakse, P. J. (2005) Residential Mortgage Securitisation: The Australian Perspective. Global Jurist Topics, 5 (3), available online http://www.bepress.com/gj/topics/vol5/iss3/art1.

Rodrik, D. (2008) One Economics, Many Recipes: Globalization, Institutions, and Economic Growth. Princeton: Princeton University Press

Rostow, W. (1960) The Stages of Economic Growth: A Non-Communist Manifesto. Cambridge: Cambridge University Press.

Sheppard, E. (2011) Geography, nature, and the question of development. Dialogues in Human Geography, 1 (1): 46-75.

Sidaway, J. D., Bryson, J. R. (2002) Constructing knowledges of 'emerging markets': UK-based investment managers and their overseas connections. Environment and Planning A, 34 (3): 401416.

Sidaway, J. D., Pryke, M. (2000) The strange geographies of 'emerging markets'. Transactions of the Institute of British Geographers, 25 (2): 187-201.

Steinmetz, G. (Ed.) (2005) The Politics of Method in the Social Sciences: Positivism and its Epistemological Others. Durham: Duke University Press.

Taylor, P. J., Ni, P., Derudder, B., Hoyler, M., Huang, J., Lu, F. Y., Pain, K., Witlox, F., Yang, X, Bassens, D., Shen, W. (2009). The way we were: command-and-control centres in the global space-economy on the eve of the 2008 geo-economic transition. Environment and Planning A, 41 (1): 7-12.

The World Bank (2011) Global Development Horizons 2011. Multipolarity: The New Global Economy. Washington: World Bank.

Thomas, A., Cox, S., Kraty, B. (Eds.) (2005) Structuring Islamic Finance Transactions. London: Euromoney Books.

Wainwright, T. (2009) Laying the foundations for a crisis: mapping the historico-geographical construction of residential mortgage backed securitization in the UK. International Journal of Urban and Regional Research, 33 (2): 372-378.

Wilson, R. (2004) Overview of the sukuk market. In Islamic Bonds: Your Guide to Issuing, Structuring, and Investing in Sukuk, J. A. Nathif, T. Abdulkader (Eds.): 3-17, London: Euromoney Books.

Wrigley, N., Overman, H. (2010) The 10th year of the Journal of Economic Geography: A decade of high impact publication. Journal of Economic Geography, 10 (1): 1-8.

Yeung, H. (2004) Chinese Capitalism in a Global Era: Towards Hybrid Capitalism. London: Routledge.

Zeitlin, J., Herrigel, G. (2000) Americanization and its limits: reworking US technology and management in post-war Europe and Japan. Oxford: Oxford University Press. 